\title{
Aplikasi Teknologi Budidaya Kelengkeng Super Sleman di Padukuhan Gejayan
}

\author{
BUDI SETIADI DARYONO ${ }^{1 *}$, ANNAS RABBANI ${ }^{1}$, PURNOMO ${ }^{2}$ \\ ${ }^{1}$ Lab. Genetika dan Pemuliaan, Fakultas Biologi, Universitas Gadjah Mada \\ ${ }^{2}$ Lab. Sistematika Tumbuhan, Fakultas Biologi, Universitas Gadjah Mada \\ Jl. Teknika Selatan, Sekip Utara, Yogyakarta 55281 \\ *email: bs_daryono@mail.ugm.ac.id
}

Manuscript received: 2 November 2015 Revision accepted: 8 Januari 2016

\begin{abstract}
Longan (Dimocarpus longan L.) is not an indigenous fruit from Indonesia. Thus, the demands for this fruit were supplied by importing them from nearby countries such as Vietnam, Thailand, and China. Longan has been cultivated and developed in Indonesia in order to supply the local needs and to reduce the rapid flows of importing Longan. Recently, a brand new breed of local Longan has been engineered from Sleman District of D.I.Yogyakarta Province, known as Kelengkeng Super Sleman (KSS). The KSS well adapted to medium-high above sea level- terrain, the most typical terrain in Sleman. Some prosperous features of this Longan cultivar were had a short harvesting time ( 2 years), thicky flesh, low water content, and able to be induced twice per year for flowering (to produce fruits). All of this goodness thus been introduced to rural communities of Padukuhan Gejayan, Desa Condongcatur, Depok, Sleman, D.I.Yogyakarta by a well designed community service programme. The kind of activites that was going on in this programme were workshop, training, and assistance. Workshop was emphasized on the prospectous consequences of planting Longan trees (KSS) for a long term until could be developed into local industrial product (One Village One Product/OVOP concept), basic knowledge on Longan diversity, KSS cultivation technology, basic knowledge on plant physiology, environmental development based on Education for Sustainable Development (EfSD), and potential local market for KSS. Training was mainly focused on KSS seedling production by both apical stem grafting method and medium preparation method, KSS plantation in some villager houses for a pilot project on how to maintain KSS such as health evaluation, health recovery for infested or unhealthy plant, method on lateral branching development, method on hormone-induced flowering, and application of resting period for afterharvesting plant. Assistance has been actively conducted during training to motivates villager to be get involved. Some positive indicators for implementation of this programme are both the great enthusiasm on KSS Longan plantation in communities and "the shifting paradigm" on KSS Longan maintenance for which has been long considered to be both impractical and arduous.
\end{abstract}

Keywords: Kelengkeng Super Sleman (KSS), cultivation technology, One Village One Product (OVOP)

\section{PENDAHULUAN}

Kelengkeng (Dimocarpus longan L.) bukanlah tanaman asli Indonesia, melainkan berasal dari negeri Cina, sehingga tergolong tanaman subtropis. Buah kelengkeng memiliki banyak khasiat mulai dari kulit buah, daging buah, bahkan bijinya. Sejak zaman dahulu hingga saat ini, daging buah kelengkeng kering digunakan di dalam teknik pengobatan China (Yunchalad et al., 2008). Ekstrak air kulit buah kelengkeng mengandung senyawa anti-oksidan dan anti-inflamasi (Huang et al., 2012) sedangkan ekstrak biji buah kelengkeng mengandung senyawa anti-mikrobia yang berasal dari senyawa fenolik (Tseng et al., 2014).

Kelengkeng di Indonesia sudah cukup lama dibudidayakan dan terdapat beberapa varietas antara lain: Kelengkeng Lokal, Pingpong, dan Diamond River dari Vietnam, kelengkeng Itoh dari Thailand dan Malaysia. Di Indonesia, kelengkeng banyak ditemukan di Pulau Jawa yang tersebar di beberapa kabupaten, antara lain Ambarawa, Magelang, Temanggung, Wonogiri di Jawa Tengah, dan Tumpang di Jawa Timur. Baru-baru ini, beberapa pekebun/petani telah berhasil mengembangkan kelengkeng di dataran rendah seperti di daerah Selarong,
Kabupaten Bantul yang dikenal dengan varietas Selarong (Sutopo, 2011). Di lokasi yang lain, di Kabupaten Sleman, juga berhasil mengembangkan varietas baru yang dikenal dengan Kelengkeng Super Sleman (KSS) (komunikasi pribadi dengan Yusuf Sukri Sulaiman, S.I.P., 2015).

Pertambahan jumlah penduduk yang diikuti oleh peningkatan kesejahteraan dan kesadaran masyarakat terhadap gizi akan mengarah pada peningkatan permintaan masyarakat terhadap buah-buahan. Pada tahun 2012, impor kelengkeng dilakukan hanya dengan 3 negara, yaitu dari Thailand sebanyak 29.000 ton kelengkeng dengan nilai US\$ 33.700.000, dari negara Vietnam sebanyak 171 ton dengan nilai US\$201.700, dan dari China sebanyak 27,5 ton dengan nilai US\$ 30.287 sejak Januari-Juni 2012 (El Hida, 2012). Sepanjang tahun 2013, kelengkeng impor telah masuk sekitar 120.000 ton dengan nilai US\$ 138.500.000 (El Hida, 2013). Lonjakan impor kelengkeng sebesar 91.000 ton dalam kurun waktu satu tahun (20122013) mengindikasikan adanya permintaan pasar yang sangat besar terhadap buah kelengkeng.

Buah kelengkeng merupakan buah non klimakterik/mengalami pematangan di pohon sehingga tidak dapat diperam. Kesegaran buah kelengkeng yang 
dipetik langsung dari kebun jauh lebih baik dibanding buah kelengkeng hasil pengiriman menggunakan kapal/pesawat terbang (buah impor). Selain itu, buah kelengkeng cepat mengalami kerusakan pada suhu rendah $\left(4^{\circ} \mathrm{C}\right)$ karena terjadi malformasi kulit buah, kulit yang semula kering menjadi menyerap air lalu mengalami pembengkakan dan pada akhirnya ter disintegrasi (Noichinda et al., 2015). Keberadaan buah kelengkeng segar hasil produksi kebun lokal yang mampu ditampung pasar-pasar di sekitar lokasi kebun memiliki peluang yang sangat besar untuk menggeser dominasi buah kelengkeng impor. Peluang ini sudah mulai dilakukan, misalnya di daerah Desa Tlogo, Prambanan, Klaten yang dikelola oleh H. Isto Suwarno. Beliau mengembangkan buah kelengkeng Itoh dari Thailand yang sangat cocok ditanam di dataran rendah dan pembuahannya bisa diprogram. Produksi buah di luar musim dapat dilakukan dengan teknologi pemeliharaan yaitu induksi pembentukan bunga menggunakan hormon pembungaan. Pohon buah kelengkeng Itoh mengalami panen perdana setelah usia 2,5 tahun pemeliharaan mulai dari awal pembibitan. Respon masyarakat cukup positif, terbukti dengan pembukaan lahan baru untuk produksi kelengkeng di daerah Kebondalem Lor, Prambanan, Klaten, dan Brorobudur, Magelang (Iswantoro, 2013).

Buah kelengkeng Super Sleman merupakan varietas kelengkeng lokal baru hasil budidaya warga Sleman (Yusuf S. Sulaiman, S.I.P.) yang telah dikembangkan di daerah Sleman dan sekitarnya. Keunggulan buah kelengkeng Super Sleman tidak kalah dengan buah kelengkeng Itoh dari Thailand yaitu sama-sama memiliki daging buah yang tebal, biji kecil, dan tidak berair. Akan tetapi, varietas lokal ini memliki usia genjah yang lebih pendek, yaitu mampu menghasilkan buah perdana pada usia 2 tahun, 6 bulan lebih cepat daripada buah kelengkeng Itoh.

\section{Tujuan}

Tujuan dari kegiatan ini adalah untuk melakukan sosialisasi dan pembinaan kepada warga Padukuhan Gejayan, khususnya kelompok tani mengenai teknologi penanaman dan perawatan pohon kelengkeng Super Sleman di dalam pot yang selanjutnya dapat dikembangkan untuk ditanam di lahan. Selain itu, kegiatan ini juga bertujuan untuk mendorong kelompok petani dan warga Padukuhan Gejayan untuk berinvestasi di dalam pengembangan buah kelengkeng Super Sleman dengan menanam pohon kelengkeng Super Sleman di dalam pot di lahan/halaman rumah masing-masing

\section{METODE}

Metode pelaksanaan dibagi menjadi 3 tahap yaitu:

\section{Penyuluhan}

Penyuluhan dilakukan dengan ceramah dan tanya jawab dengan kelompok petani dan warga Padukuhan Gejayan. Dalam penyuluhan ini dilakukan sosialisasi hasil-hasil penelitian yang telah dicapai Laboratorium Genetika Fakultas Biologi UGM mengenai budidaya tanaman kelengkeng Super Sleman.

\section{Pelatihan}

Pelatihan teknologi penanaman dan perawatan dilakukan sesuai dengan tahapan teknologi penanaman dan perawatan kelengkeng Super Sleman. Petani akan dilatih mengenai tahap-tahap teknik penyiapan media tanam, teknik sambung pucuk, evaluasi kesehatan tanaman, teknik perawatan khusus untuk proses recovery tanaman yang sakit, teknik pemotongan tunas apikal (memperbanyak cabang sehingga tanaman mampu menghasilkan lebih banyak buah), suplai nutrisi yang mencukupi, induksi pembungaan memanfaatkan hormon pembungaan, dan program "fase istirahat" pasca produksi buah.

\section{Pendampingan Berkala}

Selama pelaksanaan kegiatan dilakukan juga pembekalan, monitoring, dan pendampingan kepada perwakilan kelompok tani. Hal ini dimaksudkan agar terjadi transfer ilmu antar petani demi terwujudnya kemandirian setelah kegiatan berakhir.

\section{HASIL DAN ANALISIS DATA}

\section{Penyuluhan}

Kegiatan penyuluhan kepada kelompok tani dan warga Padukuhan Gejayan diawali dengan pengenalan konsep One Village One Product /OVOP beserta beberapa contoh pedesaan yang sukses mengembangkan OVOP di Indonesia (Gambar 1.). OVOP pertama kali dikembangkan di perfektur Oita, Jepang oleh gubernur Dr. Morihiko Hiramatsu pada tahun 1979 untuk mendorong warga pedesaan untuk menproduksi produk lokal unggulan yang potensial untuk dijual untuk skala nasional bahkan global (Kurokawa et al., 2010). Dilanjutkan dengan pengenalan keanekaragaman kelengkeng yang sudah berhasil dibudidayakan di Indonesia, teknologi budidaya kelengkeng Super Sleman, konsep dasar fisiologi tumbuhan, prospek pemasaran kelengkeng Super Sleman, dan konsep dasar pengembangan lingkungan berbasis Education for Sustainable Development (EfSD).

(a)

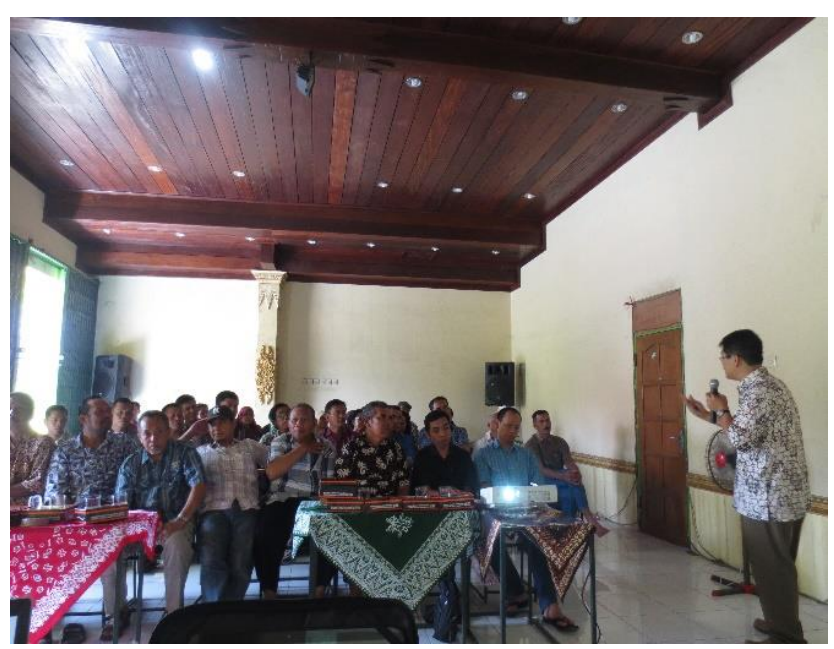




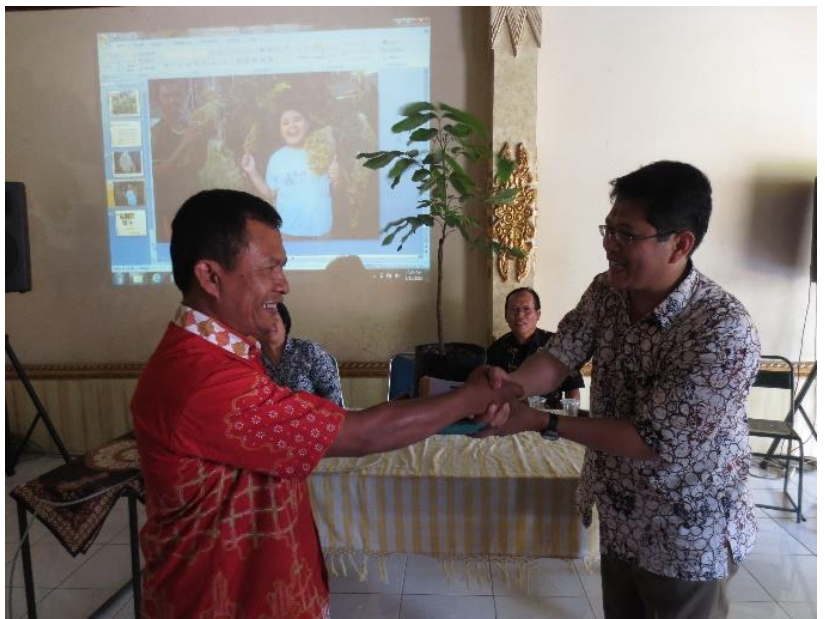

(b)

Gambar 1. Penyuluhan budidaya kelengkeng Super Sleman dan serah terima bibit KSS kepada Kepala Padukuhan Gejayan (kiri), H. Nuryanto dari tim peneliti (kanan), Dr. Budi S. Daryono, M.Agr.Sc.
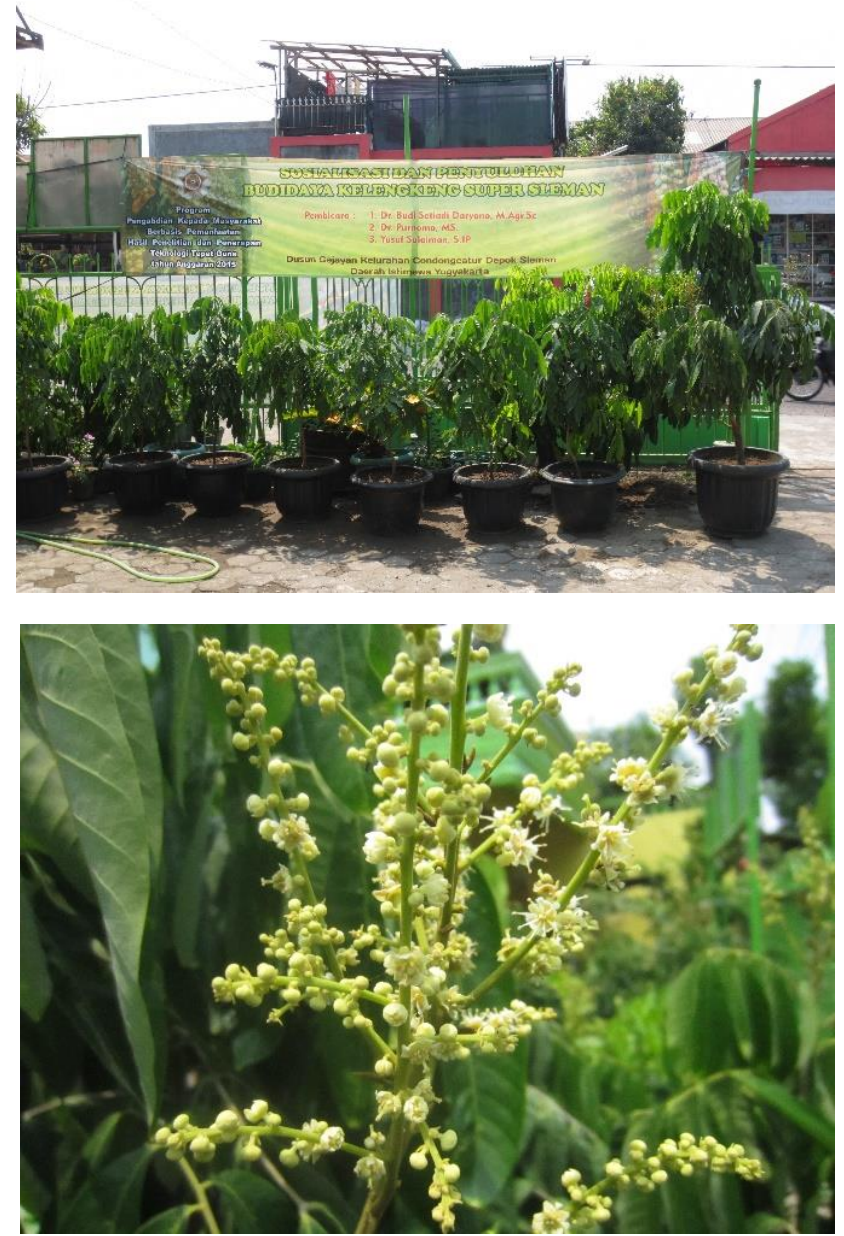

Gambar 2. Kiri: Pohon KSS di dalam pot dengan usia 1 tahun (paling kanan berusia 2 tahun). Kanan: Pohon KSS usia 2 tahun setelah 45 hari pasca aplikasi hormon pembungaan

\section{Pelatihan Teknologi Budidaya Kelengkeng Super Sleman (KSS)}

Pelatihan secara mendasar dibagi menjadi beberapa tahapan yaitu persiapan media tanam, perbanyakan bibit KSS, perawatan tanaman, dan induksi pembungaan.

Persiapan media tanam terdiri dari dua metode yaitu pengayakan tanah dan pembuatan media karantina. Media karantina adalah media transisi untuk kelengkeng kultivar non-KSS yang akan digunakan sebagai batang bawah dalam teknik sambung pucuk. Media ini terdiri dari campuran tanah hasil ayakan dan pupuk kandang di dalam polibag dengan ukuran sedang.

Perbanyakan bibit KSS dilakukan dengan teknik sambung pucuk yaitu mengambil tunas lateral dari pohon KSS dewasa kemudian disambungkan pada kelengkeng non-KSS yang digunakan sebagai batang bawah. Setelah kurang lebih 3 bulan, dengan indikasi daun yang tumbuh dari tunas lateral KSS berwarna hijau cerah, lebar, dan lebat. Pada tahap ini, bibit KSS siap dipindahkan ke dalam pot.

Perawatan tanaman di dalam pot dilakukan kurang lebih selama 2 tahun dan selanjutnya dapat dipindahkan untuk ditanam secara permanen di tanah/lahan. Perawatan meliputi penyiraman rutin pada pukul 06.00 dan 16.00 waktu setempat, pemupukan rutin seminggu sekali menggunakan pupuk kandang dari kotoran kambing, penggantian atau penambahan tanah, penanggulanagn hama dan gulma, dan teknik recovery tanaman yang sakit. Aplikasi pupuk kandang secara umum mampu meningkatkan unsur hara tanah, terutama apabila tanah yang dipergunakan memiliki kandungan unsur hara yang rendah (Gulshan et al., 2013).

Pohon KSS di dalam pot yang kurang lebih berusia 1 tahun 7 bulan yang memiliki batang dengan keliling kurang lebih $5 \mathrm{~cm}$ sudah mampu dibungakan melalui aplikasi pupuk pengembang bunga (hormon) yang sudah banyak dijual secara umum, misalnya Nongfeng ${ }^{\circledR}$. Pupuk pengembang bunga khusus untuk umumnya memiliki kandungan potassium chlorate $\left(\mathrm{KClO}_{3}\right)$ yang memiliki fungsi vital dalam proses pembungaan pohon kelengkeng (Matsumoto et al., 2007). Pada saat dilakukan aplikasi hormon, 2 hari berikutnya pasca aplikasi hormon tidak boleh dilakukan penyiraman. Hal ini bertujuan supaya hormon dapat terserap secara optimal. Bunga akan bermunculan 45 hari pasca aplikasi hormon pembungaan (Gambar 2.). Pemupukan rutin seminggu sekali menggunakan pupuk kandang dari kotoran kambing tetap dilakukan sebagai sumber nutrisi tambahan untuk perkembangan bunga. Bunga harus selalu dijaga pertumbuhannya dengan penyemprotan hormon pada daun maupun bunga. Satu bulan berikutnya, bunga akan rontok menjadi buah.

Aplikasikan pupuk NPK secara periodik, 2 minggu sekali, dengan tujuan memaksimalkan kualitas buah KSS. Selain itu, aplikasi pupuk kandang dari kotoran kambing (1 minggu sekali) dan pupuk NPK (2 minggu sekali) akan menjaga rasio $\mathrm{C}: \mathrm{N}$ tetap tinggi sehingga menjaga pohon kelengkeng dalam kondisi fisiologis fase generatif (Corbesier et al., 2002). Faktor kunci dalam menjaga rasio tinggi C:N (berkisar antara 30:1 sampai 28:1) adalah kandungan pupuk kandang dari kotoran kambing yang 
memiliki unsur karbon (C) yang tinggi dan unsur nitrogen (N) yang rendah dibanding dengan pupuk kandang dari kotoran kerbau, unggas, sapi, dan unta (Irshad et al., 2013).

Produksi buah terus berlangsung selama 3 bulan sehingga pada akhir bulan ke-3 total jumlah buah dapat dihitung. Buah yang akan terbentuk bervariasi dengan kisaran $80-90 \%$ dari total jumlah bunga. Panen dapat dilakukan pada akhir bulan ke-3. Pasca panen, tanaman diistirahatkan selama 4 bulan supaya mampu berbunga kembali. Kemudian dilanjutkan dengan aplikasi hormon pada 1 bulan berikutnya, diikuti panen pada 4 bulan berikutnya, dan seterusnya. Dalam satu tahun, dapat dilakukan 2 kali masa panen dengan interval 6 bulan-6 bulan (bulan ke-1: aplikasi hormon, bulan ke: 2-4: produksi buah dan panen, bulan ke-5-8: fase istirahat, bulan ke-9: aplikasi hormon, bulan ke-10-12: produksi buah dan panen), dan seterusnya (siklus diulang kembali pada tahun berikutnya).

\section{Pendampingan Berkala}

Pendampingan berkala dilakukan terhadap petani model. Pendampingan dilakukan oleh ahli dan praktisi budidaya kelengkeng Super Sleman. Pendampingan dilakukan selama 5 bulan perawatan bibit KSS di dalam pot. Pendampingan dilakukan secara aktif meliputi evaluasi kesehatan tanaman, penanggulangan terhadap serangan hama, induksi pembungaan dengan hormon, dan perbanyakan bibit KSS dengan teknik sambung pucuk.

\section{Analisis Ekonomi}

Investasi awal budidaya kelengkeng Super Sleman terbesar adalah perawatan secara berkala selama 2 tahun meliputi pemupukan dengan pupuk kandang secara berkala dan penggantian media tanam khusus untuk tanaman yang terkena penyakit (Tabel. 1).

Pasar-pasar potensial berada cukup dekat dengan lokasi penanaman (Padukuhan Gejayan) sehingga biaya transportasi relatif murah. Selain itu, dengan kualitas yang lebih baik dan kesegaran yang terjamin, pasar-pasar akan beralih dari pembelian kelengkeng impor ke pembelian kelengkeng Super Sleman.

Tabel 1. Analisis Ekonomi Budidaya Kelengkeng Super Sleman

\begin{tabular}{|c|c|c|}
\hline \multicolumn{2}{|c|}{$\begin{array}{l}\text { Total keuntungan penjualan } 50 \text { pot pohon } \\
\text { buah kelengkeng Super Sleman/1 tahun }\end{array}$} & $\begin{array}{l}\text { Jumlah } \\
\text { (Rp) }\end{array}$ \\
\hline Penjualan & $\begin{array}{l}\text { Rp. } 30.000 / \mathrm{kg} \times \mathbf{2} \text { (1 ranting, } \\
\text { minimal } 2 \mathrm{~kg}) \times \mathbf{5} \text { (1 pohon, } \\
\text { minimal } 5 \mathrm{ranting}) \times \mathbf{2}(1 \text { pohon, } \\
2 \text { kali panen/tahun) x } \mathbf{5 0}\end{array}$ & 30.000 .000 \\
\hline $\begin{array}{l}\text { Biaya } \\
\text { Produksi }\end{array}$ & $\begin{array}{l}\text { Rencana Anggaran Belanja } \\
\text { (Lampiran) dengan scaling-up } \\
\text { untuk produksi } 1 \text { tahun (pupuk } \\
\text { kandang, sekam, hormon } \\
\text { pembungaan) x } 2\end{array}$ & 20.000 .000 \\
\hline \multirow[t]{2}{*}{$\begin{array}{l}\text { Biaya } \\
\text { Transportasi }\end{array}$} & $\begin{array}{l}\text { Biaya transportasi ditanggung } \\
\text { oleh pedagang dari pasar-pasar } \\
\text { potensial (pasar terdekat tidak } \\
\text { lebih dari } 5 \mathrm{~km} \text { ) }\end{array}$ & 500.000 \\
\hline & Laba & $\begin{array}{c}\text { Rp. } \\
9.500 .000\end{array}$ \\
\hline
\end{tabular}

\section{KESIMPULAN}

Warga Padukuhan Gejayan telah mengalami perubahan paradigma terkait budidaya kelengkeng yang selama ini dipandang sebagai suatu upaya yang sukar dilakukan. Warga Padukuhan Gejayan secara umum telah memahami penerapan teknologi pertanian tepat guna Kelengkeng Super Sleman mulai dari perbanyakan bibit, perawatan, hingga pembungaan serta beberapa faktor kunci di dalam perawatan antara lain aplikasi pupuk kandang dari kotoran kambing setiap seminggu sekali, induksi pembungaan pada usia yang tepat, dan aplikasi pupuk NPK setiap 2 minggu sekali selama fase berbuah. Dengan dukungan penuh warga dan kelompok petani Padukuhan Gejayan, penanaman pohon Kelengkeng Super Sleman diharapkan mampu menjadi suatu tren/budaya di dalam lingkungan Padukuhan Gejayan.

\section{UCAPAN TERIMA KASIH}

Penelitian ini didanai oleh Biaya Operasional Perguruan Tinggi Negeri Badan Hukum (BOPTN BH) Universitas Gadjah Mada No: 022/SP/LPPM-DIT.KEU/DIPA/ UGM/2015 melalui

Program Pengabdian kepada Masyarakat Berbasis Pemanfaatan Hasil Penelitian dan Penerapan Teknologi Tepat Guna. Penulis mengucapkan terima kasih kepada H. Nuryanto selaku Kepala Padukuhan Gejayan, Desa Condongcatur, Kecamatan Depok, Kabupaten Sleman, D.I.Yogyakarta, Yusuf S. Sulaiman, S.I.P. selaku Ketua Kelompok Tani Kelengkeng Super Sleman Padukuhan Gejayan, dan warga Padukuhan Gejayan.

\section{REFERENSI}

Corbesier, L., Bernier, G., Perilleux, C. (2002). C:N Ratio Increases In The Phloem Sap During Floral Trantition of The Long-Day Plants Sinapsis alba and Arabidopsis thaliana. Plant Cell Physiol.,(43): 684-688.

El hida, R. (2012). Indonesia Beli Buah Impor Rp 8 Triliun di 2012. http://finance.detik.com/read/2013/02 /06/141608/2162689/4/ indonesia-beli-buah-impor-rp-8-triliun-di-2012. Diakses pada tanggal: 21 Maret 2015.

El hida, R. (2013). Ini Dia 9 Buah Impor Favorit Indonesia. http://finance.detik.com /read/2012 /08/03/095600/1982145/4/6/ ini-dia-9-buah-impor-favorit-indonesia. Diakses pada tanggal: 21 Maret 2015.

Gulshan, A.B., Saeed, H.M., Javid, S., Meryem, T., Atta, M.I., Amin-udDin, M. (2013). Effects of Animal Manure on The Growth and Development of Okra (Abelmoschus esculentus L.). ARPN Journal of Agricultural and Biological Science, Vol.8(3): 213-218.

Huang, G., Wang, B., Lin, W., Huang, S., Lee, C., Yen, M., Huang, M. (2012). Antioxidant and Anti-Inflammatory Properties of Longan (Dimocarpus longan Lour.) Pericarp. Evidence-Based Complementary and Alternative Medicine.

Irshad, M., Eneji, A.E., Hussain, Z., Ashraf, M. (2013). Chemical Characterization of Fresh and Composted Livestock Manures. Journal of Soil Science and Plant Nutrition, 13(1): 115-121. 
Iswantoro. (2013). Itoh Terbaik di Antara Kelengkeng Lain. http://krjogja.com /read/163249 /itoh-terbaik-di-antarakelengkeng-lain. (21/03/2015).

Komunikasi Pribadi. (2015). Teknologi Penanaman, Teknologi Perawatan, dan Prospek Ekonomis Kelengkeng Super Sleman. Yusuf Sukri Sulaiman, S.I.P. (21 Maret 2015).

Kurokawa, K., Tembo, F., te Velde, D.W. (2010). Challenge for The OVOP Movement in Sub-Saharan Africa: Insight from Malawi, Japan and Thailand. Japan International Cooperation Agency Research Institute.

Matsumoto, T.K., Tsumura, T., Zee, F. (2007). Exploring The Mechanism of Potassium Chlorate-Induced Flowering in Dimocarpus longan. Acta Hort., (738): 451-457.
Noichinda, S., Bodhipadma, K., Tusvil, P., Sathitwiangthong, U., Sangudom, T., Ketsa, S. (2015). The Physiology of Chilling Injured Longan Fruit. The Journal of Applied Science, Vol.14(1): 1-8.

Sutopo. (2011). Potensi Pengembangan Lengkeng di Dataran Rendah https://kpricitrus .wordpress .com/2011/04/04/potensipengembangan-lengkeng-di-dataran-rendah/. 21/03/2015.

Tseng, H., Wu, W., Huang, H., Wu, M. 2014.Antimicrobial Activities of Various Fractions of Longan (Dimocarpus longan Lour. Fen Ke) Seed Extract. International Journal of Food Science and Nutrition, Vol.65(5): 589-593.

Yunchalad, M., Supasri, R., Boonbamrung, S., Wongkrajank, K., Hiraga, C., Watanasook, A. 2008. Pre-concentration of Longan Juice Extract with Microfiltration and Reverse Osmosis. As. J. Food AgInd, (01): 17-2 